\title{
RELATIVE ABUNDANCE OF NICROPHORUS PUSTULATUS (COLEOPTERA: SILPHIDAE) IN A BURYING BEETLE COMMUNITY, WITH NOTES ON ITS REPRODUCTIVE BEHAVIOR
}

\author{
BY IAN C. ROBERTSON ${ }^{1}$ \\ Department of Zoology \\ Erindale College \\ University of Toronto, Mississauga \\ Ontario, L5L 1C6, Canada
}

\section{INTRODUCTION}

Recently, there has been considerable interest in competitive interactions between sympatric species of burying beetles (Silphidae, Nicrophorus) which use small (mouse- to rat-sized) vertebrate carrion in reproduction (Wilson et al., 1984; Müller and Eggert, 1987; Kozol et al., 1988; Trumbo, 1990a, 1990b, 1992). However, the extent of resource competition between $N$. pustulatus Herschel and other burying beetles has remained enigmatic because $N$. pustulatus have never been found on small vertebrate carcasses in nature (Wilson et al., 1984; Trumbo, 1990a), and their reproductive behavior is virtually unknown. In this paper I examine the relative abundance of $N$. pustulatus in an eastern Ontario burying beetle community, as well as its reproductive behavior in the laboratory. My goal is to provide information aimed at improving our understanding of competitive relationships between $N$. pustulatus and other burying beetles.

Burying beetles conceal and defend small vertebrate carrion below ground as a food resource for themselves and their offspring. Males and females attracted to carrion engage in intense intrasexual combat, with the largest male and female usually remaining to bury the carcass (Wilson and Fudge, 1984; Bartlett and Ashworth, 1988). The pair excavate a narrow space around the interred carcass (forming a crypt), strip the carcass of fur or feathers, and cover it with anal secretions that prevent fungal growth

\footnotetext{
${ }^{1}$ Present Address: Dept. of Biological Sciences, Simon Fraser University, Burnaby, British Columbia, V5A 1S6, Canada Manuscript received 26 March 1992
} 
(Pukowski, 1933; Fetherston et al., 1990). Eggs are typically oviposited in the soil surrounding the carcass and hatch a few days later. Both parents feed their larvae regurgitated carrion and defend them against invertebrate predators, including other burying beetles (Fetherston et al., 1990; Scott, 1990). In all species studied so far, duration of male care is usually less than that of the female (Pukowski, 1933; Bartlett, 1988; Scott and Traniello, 1990).

Although N. pustulatus is widespread in its distribution (Anderson and Peck, 1985; Peck and Kaulbars, 1987), little information is available on its reproductive activities. Anomalies in this species' behavior suggest that its life history is different from that of its congeners. Unlike other Nicrophorus species, $N$. pustulatus are only infrequently collected in traps baited with carrion, and they are more commonly captured at lights (Anderson, 1982; Wilson $e t$ al., 1984). Furthermore, Wilson et al. (1984) and Trumbo (1990a) report that $N$. pustulatus were never attracted to $15-40 \mathrm{~g}$ dead mice placed in the field, whereas congeners such as $N$. orbicollis were among the first scavengers to arrive at those carcasses. Trumbo (1990a, 1992) suggests that because N. pustulatus in the laboratory readily breed on carcasses greater than $100 \mathrm{~g}$, they probably specialize on these larger carcasses in nature. My objective in this study was threefold: to examine the relative abundance of $N$. pustulatus in a burying beetle community, to describe their parental care behavior, and to determine whether they are capable of reproducing on vertebrate carcasses similar in size to those used by $N$. orbicollis, a common species which is reproductively active at the same time as $N$. pustulatus. I also discuss possible reasons why $N$. pustulatus does not occur on such small vertebrate carrion in nature, and directions for future research.

\section{Study AREA ANd Methods}

Research was conducted at Queen's University Biological Station in eastern Ontario $\left(44^{\circ} 34^{\prime} \mathrm{N}, 76^{\circ} 19^{\prime} \mathrm{W}\right)$ from 1 June to 31 August 1991. The biology station is situated on a 7 ha point bordering Lake Opinicon, with the habitat consisting of mixed-deciduous forest and early successional old field, along with some permanent marshes. I collected burying beetles at night at least four times per week from traps $(8.5 \mathrm{~cm}$ high $\times 5.0 \mathrm{~cm}$ diameter 
cups) baited with $30 \mathrm{~g}$ of ground beef and suspended from trees at a height of 1 to $2 \mathrm{~m}$ above ground. A $20 \mathrm{~cm}^{2}$ cardboard collar was placed in a horizontal plane around the top rim of the cup to provide a landing platform for incoming beetles. Thirteen traps were placed 50 to $150 \mathrm{~m}$ apart along a gravel road adjacent to forest. In addition to $N$. pustulatus, I captured $N$. defodiens, $N$. orbicollis, $N$. sayi, and $N$. tomentosus in the traps. I measured pronotum widths of $N$. pustulatus and $N$. orbicollis to an accuracy of $0.05 \mathrm{~mm}$. I only measured those $N$. orbicollis captured in June since data from 1990 indicated that there was no seasonal change in the distribution of their body sizes (unpublished data).

Breeding experiments using $N$. orbicollis and $N$. pustulatus were conducted in the laboratory in the fall of 1991 and early 1992. I included $N$. orbicollis in order to compare the breeding success of a species commonly found on small vertebrate carcasses with that of a species never found on small vertebrate carcasses. All $N$. orbicollis used were wild-caught individuals $(N=18$ pairs $)$, while $N$. pustulatus included both wild-caught and laboratoryreared individuals $(N=13$ pairs). Experimental protocol was identical for both species. A newly-thawed laboratory mouse (Mus musculus), weighing between 15 and $35 \mathrm{~g}$, was placed in a $0.5 \mathrm{~L}$ clear plastic container filled with potting soil. I placed a male and female beetle with each mouse carcass, and then covered the container with an inverted $0.5 \mathrm{~L}$ container. The cover ensured that the mouse was kept within the container during burial; it was removed after $24 \mathrm{~h}$. Pairs of beetles were maintained at room temperature and exposed to natural (summertime) photoperiod. I checked the containers two to four times daily and recorded timing of carcass burial, onset of both oviposition and hatching, timing of larval dispersal from the carcass, and duration of parental care (i.e. the number of days before a parent abandoned its nest). I counted and weighed larvae once they dispersed from the carcass, and I placed them at room temperature to pupate in $0.5 \mathrm{~L}$ containers (up to five larvae per container) filled with potting soil.

\section{RESULTS}

\section{The burying beetle community}

Relative abundances of the five species of Nicrophorus captured in traps are shown in Fig. 1. N. orbicollis was the dominant species 


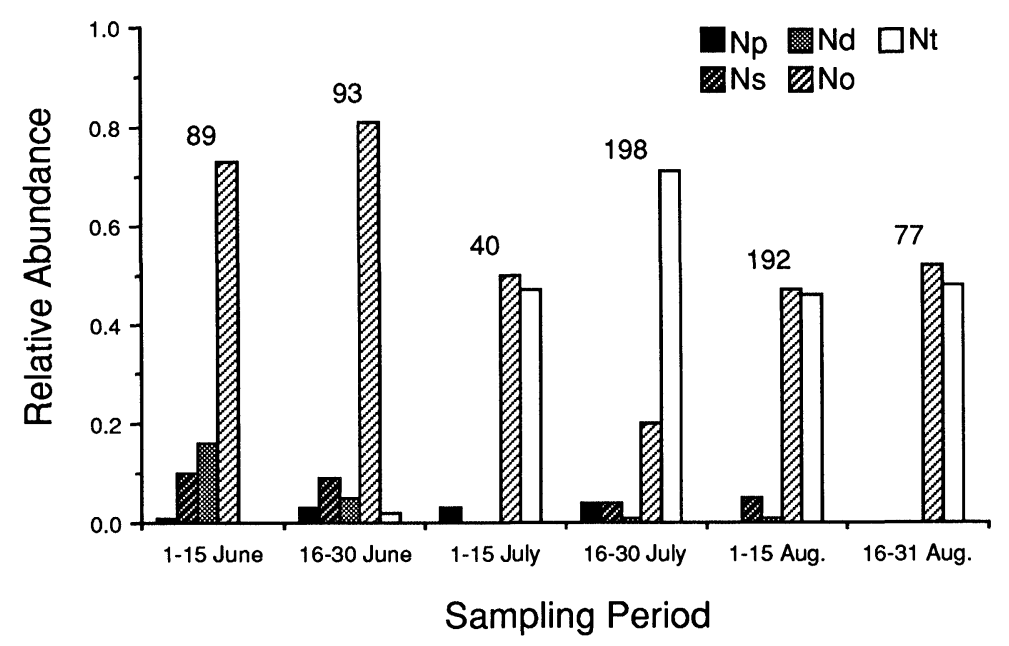

Figure 1. Relative abundances of Nicrophorus species. Sample sizes are shown above the bars. $\mathrm{Np}=N$. pustulatus, $\mathrm{Ns}=N$. sayi, $\mathrm{Nd}=N$. defodiens, $\mathrm{No}=N$. orbicollis, $\mathrm{Nt}=N$. tomentosus.

in June, but this dominance was shared with $N$. tomentosus in early July and throughout August. $N$. defodiens and $N$. sayi were most common in early June, but neither was abundant relative to $N$. orbicollis or $N$. tomentosus. $N$. pustulatus had relatively constant but poor representation in the traps throughout June and July, its numbers never exceeding $4 \%$ of the burying beetles captured. $N$. pustulatus was the only species found at lights at my study site, but these data were not collected quantitatively. The presence of $N$. orbicollis and $N$. sayi in August was attributable primarily to the emergence of second generation adults that were not sexually mature (i.e. they were tenerals); thus, most of these individuals would not compete for carcasses used in reproduction. $N$. tomentosus caught in June and most of July were also teneral, and reproductively active individuals did not arrive at traps until late July and early August. 


\section{Body size}

There was no evidence of differences in mean body size between $N$. orbicollis and $N$. pustulatus caught in traps. Pronotum widths of $N$. orbicollis ranged from 4.45 to $8.50 \mathrm{~mm}$ ( $\overline{\mathrm{X}} \pm \mathrm{SE}=$ $6.50 \pm 0.07, N=140$ ), while $N$. pustulatus ranged from 6.05 to 7.45 $\mathrm{mm}(6.73 \pm 0.12, N=13)$ (unpaired two-tailed t-test; $t=-1.01, d f=$ 151, $P=0.314)$. However, a variance ratio test (Zar, 1984) revealed that variance in body size was significantly greater for $N$. orbicollis $\left(F_{139,12}=11.56, P<0.001\right)$, indicating that $N$. orbicollis reached greater extremes in body size than $N$. pustulatus.

\section{Breeding behavior}

Breeding behavior of $N$. pustulatus did not differ notably from $N$. orbicollis, and in no case did individuals of either species reject a carcass. Both species buried mice within five hours of the start of an experiment, and eggs were laid along the sides of containers 36 to $72 \mathrm{~h}$ later. By this time the carcass had been rolled into a ball and most fur had been removed. Eggs hatched in about three days, and larvae dispersed into the soil once the carcass had been fully consumed, usually four days later. Total brood mass increased with carcass mass for both species (Fig. 2 ; analysis of covariance, $F_{1,28}$ $=55.78, P<0.001)$, and was higher for $N$. pustulatus when carcass mass was held constant $\left(F_{1,28}=11.61, P=0.002\right)$. The slopes of the two lines were homogeneous $\left(F_{1,27}=0.28, P=0.60\right)$. Parents of both species tended their offspring, which included regurgitation of carrion to larvae by at least one parent. Stridulatory sounds by parents, which have been suggested as a means by which parents communicate with larvae (Milne and Milne, 1976), were occasionally heard from the nest. Males of both species usually abandoned their broods a day or two before larvae dispersed into the soil. Larvae enclosed themselves in small chambers in the soil to pupate about three days after dispersing, and emerged as tenerals 22 to 27 days later. These tenerals were capable of reproduction one month after emergence. Overall, $N$. pustulatus behaved in a manner consistent with general descriptions of reproductive behavior in the genus. 


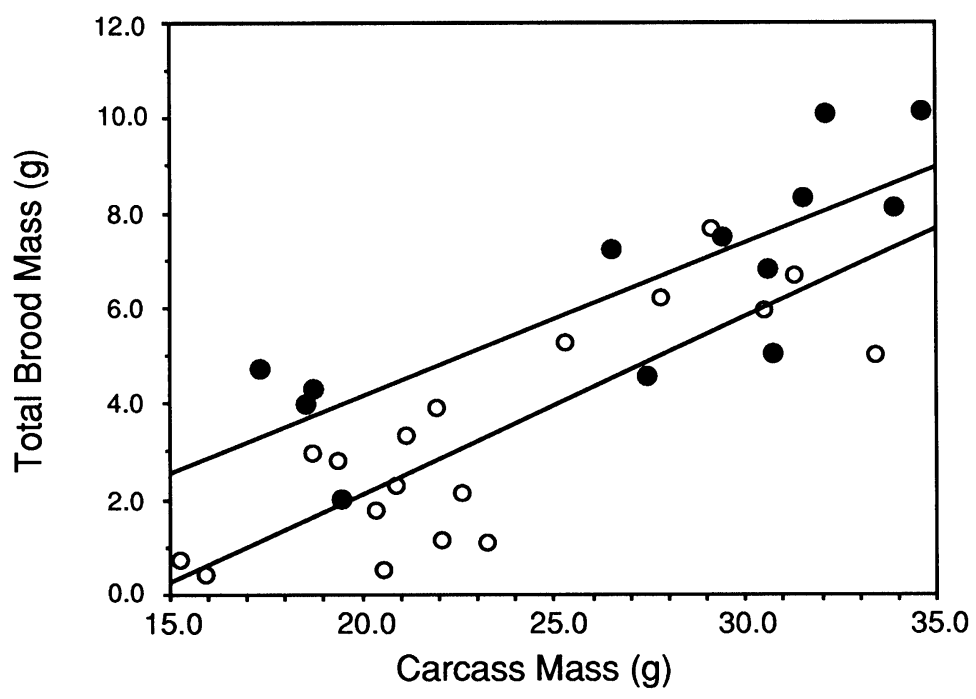

Figure 2. Relationship between carcass mass and total brood mass for N. pustulatus (filled circles) and $N$. orbicollis (open circles).

\section{DISCUSSION}

The relative abundances and seasonal distributions I found are consistent with similar studies of burying beetle communities in southern Ontario (Anderson, 1982), Michigan (Wilson et al., 1984), and North Carolina (Trumbo, 1990a). N. pustulatus were rarely captured in June and July, and were never captured in August. $N$. defodiens and $N$. sayi were also rare, but this is likely because their peak activity period is in May and early June (Anderson, 1982). $N$. orbicollis and $N$. tomentosus were abundant during their respective breeding seasons, which for $N$. orbicollis ranged from June to July, and for $N$. tomentosus began in August (unpublished data; Scott and Traniello, 1990).

According to Anderson (1982), N. pustulatus are associated with all types of forest habitat, but they are rare in meadows and absent from marshes. Because my study site was primarily mixeddeciduous forest, my inability to capture many $N$. pustulatus 
probably does not reflect a lack of suitable habitat. Moreover, it is unlikely that their low numbers were caused by sampling during the wrong time of year. Anderson (1982) reports that tenerals of $N$. pustulatus first appear in August, indicating that this species begins breeding in mid-June (since two weeks are required before larvae pupate and one month is required for pupae to emerge as tenerals). This was confirmed in the laboratory because individuals captured in early July were reproductively mature. Therefore, the poor representation of $N$. pustulatus in carrion traps suggests either that $N$. pustulatus were rare in the burying beetle community, or that they were less attracted than other burying beetles to traps baited with small amounts of carrion.

Although $N$. pustulatus were rarely caught in carrion traps, both $N$. pustulatus and $N$. orbicollis were capable of efficiently using small mouse carcasses for reproduction. Assuming that $N$. pustulatus use the same cues as other burying beetles to locate carrion, these results suggest that $N$. pustulatus were rare in the burying beetle community. However, rarity alone cannot explain their absence on small vertebrate carcasses in nature. Wilson et al. (1984) did not find $N$. pustulatus on any of the 1132 mouse carcasses placed in the field at their Michigan study site, even though $N$. pustulatus represented $1.8 \%$ of the burying beetles caught in carrion traps. Similarly, in North Carolina, Trumbo (1990a) did not find $N$. pustulatus on any of the 263 mouse carcasses he placed in the field, even though their relative abundance in pitfall traps was $5.8 \%$. Thus, while N. pustulatus may occur in relatively low numbers, their absence on small carcasses in nature suggests that they use alternative sources of carrion for reproduction.

There is laboratory evidence that $N$. pustulatus are adapted for using large carcasses (up to $260 \mathrm{~g}$ has been investigated) for reproduction. According to Trumbo (1992), while $N$. orbicollis cannot raise more than 30 to 45 young on carcasses exceeding $50 \mathrm{~g}, N$. pustulatus can raise almost 190 offspring on 220 to 260 g carcasses. This reflects an overall increase in the total number of larvae produced but not a decrease in their size. It is not known how $N$. pustulatus produce such large broods while other species cannot. However, the greater reproductive benefits to $N$. pustulatus using larger carcasses may explain why they do not use small carcasses in nature even though they are capable of using them. 
Likewise, the lack of such benefits to $N$. orbicollis may explain why they use small carcasses for reproduction, especially since small carcasses are easier than large carcasses to conceal and defend from congeners and dipterans (Trumbo, 1992), and they may be more abundant. [Trumbo (1992) found that $N$. orbicollis also use large carcasses for reproduction, but in these cases they tend to breed communally with conspecifics. It is uncertain whether their reproductive success differs between small and large carcasses.]

Although $N$. pustulatus may be more successful reproducing on large carcasses than on small ones, it seems unlikely that they would pass up opportunities to breed on small carcasses in nature since carrion is a rare and ephemeral resource. Thus, the absence of $N$. pustulatus on small carcasses may indicate that they are competitively inferior to $N$. orbicollis and other species that commonly use small carcasses. It has been demonstrated that large body size is important in contests for carcasses (Wilson et al., 1984; Bartlett and Ashworth, 1988), and under conditions of intense competition only the largest individuals in a population would be likely to secure carcasses for reproduction. Because I found that $N$. orbicollis reached a bigger extreme in body size than $N$. pustulatus (see also Anderson and Peck, 1985), it is conceivable that even the largest $N$. pustulatus are unable to secure small carcasses. Further research is required to determine whether the smallest $N$. orbicollis securing carcasses are larger than the largest $N$. pustulatus, or whether asymmetries in their fighting abilities exist independently of body size. Also, it has yet to be shown that N. pustulatus do indeed use larger carcasses for reproduction in nature. If they do, then the low availability of such carcasses relative to smaller, mouse-sized, carcasses may further explain why $N$. pustulatus are rare in burying beetle communities.

\section{SUMMARY}

$N$. pustulatus were rarely captured in pitfall traps baited with carrion whereas congeners such as $N$. orbicollis were common. Although previous studies did not find that $N$. pustulatus used small vertebrate carcasses for reproduction in nature, I found that $N$. pustulatus were capable of reproducing on small mouse carcasses in the laboratory and in a manner consistent with other 
burying beetles. In fact, $N$. pustulatus were more efficient converting carcasses into larval biomass than $N$. orbicollis, a species commonly found on small vertebrate carcasses. The absence of $N$. pustulatus on small carcasses in nature may be due to their ability to use larger carcasses for reproduction, and the greater reproductive success achieved when using such carcasses. However, further research is required to determine if $N$. orbicollis competitively exclude $N$. pustulatus from small carcasses.

\section{ACKNOWLEDGEMENTS}

I thank Queen's University for use of the biological station facilities, Rob Baker, Shelley Ball, Bill Brown, John Eadie, James Fullard, and Darryl Gwynne for helpful comments on the manuscript, Larry Craig for supplying the frozen mice, and everyone in the Brown lab at QUBS for tolerating the smell of carrion. My research was supported by Sigma Xi and by a Natural Sciences and Engineering Research Council of Canada operating grant to Darryl Gwynne.

\section{REFERENCES}

ANDERSON, R. S.

1982. Resource partitioning in the carrion beetle (Coleoptera: Silphidae) fauna of southern Ontario: ecological and evolutionary considerations. Can. J. Zool. 60: 1314-1325.

ANDERSON, R. S. AND S. B. PECK

1985. The Insects and Arachnids of Canada, Part 13: The Carrion Beetles of Canada and Alaska (Coleoptera: Silphidae and Agyrtidae). Agriculture Canada.

BARTLETT, J.

1988. Male mating success and paternal care in Nicrophorus vespilloides (Coleoptera: Silphidae). Behav. Ecol. Sociobiol. 23: 297-303.

BartLett, J. AND C. M. Ashworth

1988. Brood size and fitness in Nicrophorus vespilloides (Coleoptera: Silphidae). Behav. Ecol. Sociobiol. 22: 429-434.

Fetherston, I. A., M. P. Scott and J. F. A. Traniello

1990. Parental care in burying beetles: The organization of male and female brood-care behavior. Ethology 85: 177-190.

Kozol, A. J., M. P. Scott and J. F. A. Traniello

1988. The American burying beetle, Nicrophorus americanus: studies on the natural history of a declining species. Psyche 95: 167-176.

MiLne, L. J. AND M. MiLnE

1976. The social behavior of burying beetles. Sci. Am. 235: 84-89. 
MÜlleR, J. K. AND A. K. EgGERT

1987. Effects of carrion-independent pheromone emission by male burying beetles (Silphidae: Necrophorus). Ethology 76: 297-304.

Peck, S. B. AND M. M. Kaulbars

1987. A synopsis of the distribution and bionomics of the carrion beetles (Coleoptera: Silphidae) of the conterminous United States. Proc ent. Soc. Ont. 118: $47-81$.

Pukowski, E.

1933. Öekolgische Untersuchungen an Necrophorus F. Z. Morphol. Öekol. Tiere 27: 518-586.

ScotT, M. P.

1990. Brood guarding and the evolution of male parental care in burying beetles. Behav. Ecol. Sociobiol. 26: 31-39.

Scott, M. P. AND J. F. A. Traniello

1990. Behavioural and ecological correlates of male and female parental care and reproductive success in burying beetles (Nicrophorus spp.). Anim. Behav. 39: 274-283.

Trumbo, S. T.

1990a. Reproductive success, phenology and biogeography of burying beetles (Silphidae, Nicrophorus). Am. Midl. Nat. 124: 1-11.

1990b. Interference competition among burying beetles (Silphidae, Nicrophorus). Ecol. Entomol. 15: 347-355.

1992. Monogamy to cooperative breeding: exploitation of a broad resource base by burying beetles (Nicrophorus). Ecol. Entomol. 17: 289-298.

WILSON, D. S. AND J. FUDGE

1984. Burying beetles: intraspecific interactions and reproductive success in the field. Ecol. Entomol. 9: 195-203.

Wilson, D. S., W. G. KNOLLENBERG AND J. FudGe

1984. Species packing and temperature dependent competition among burying beetles (Silphidae, Nicrophorus). Ecol. Entomol. 9: 205-216.

ZAR, J. H.

1984. Biostatistical Analysis, 2nd Edition. Prentice-Hall, New Jersey. 

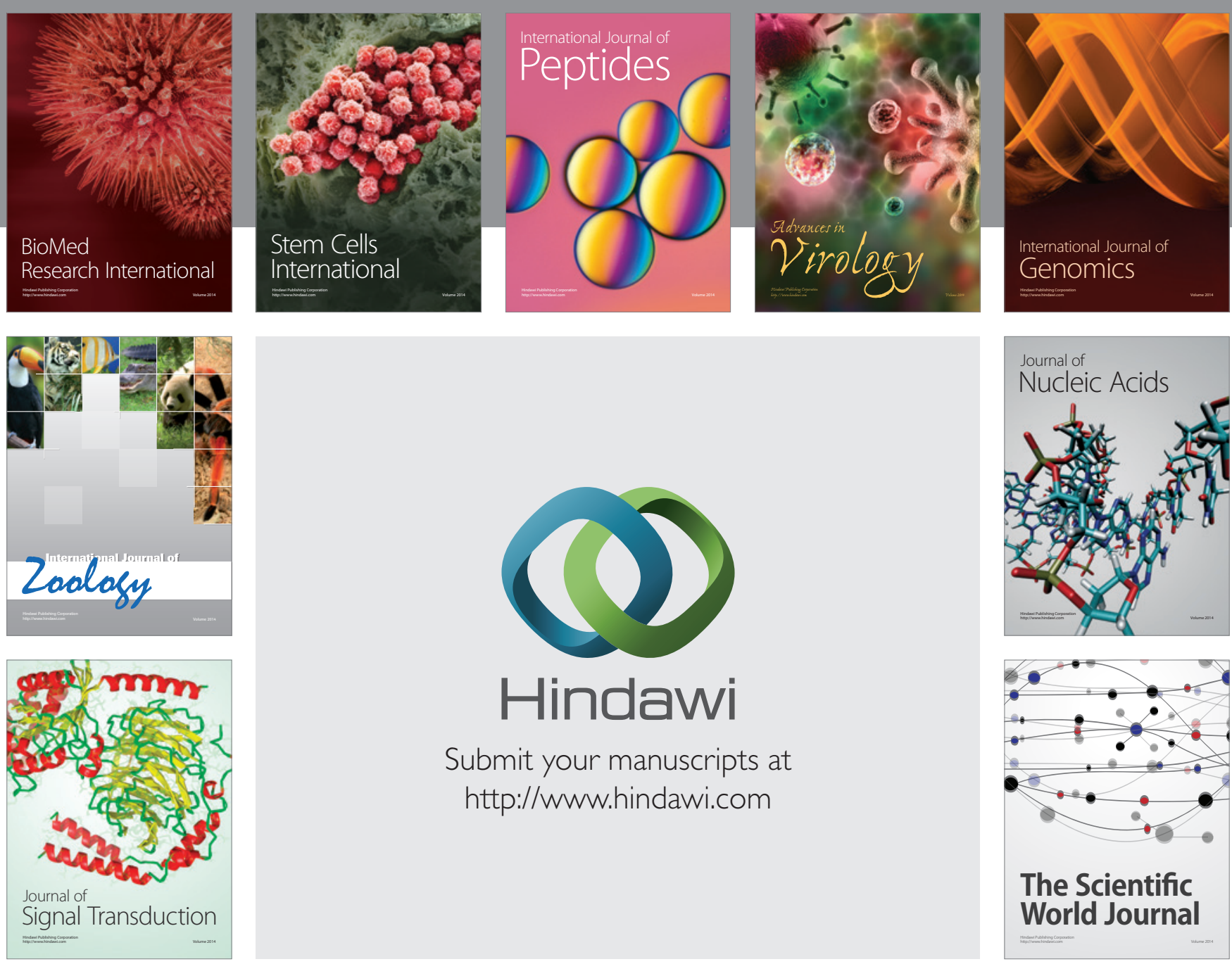

Submit your manuscripts at

http://www.hindawi.com
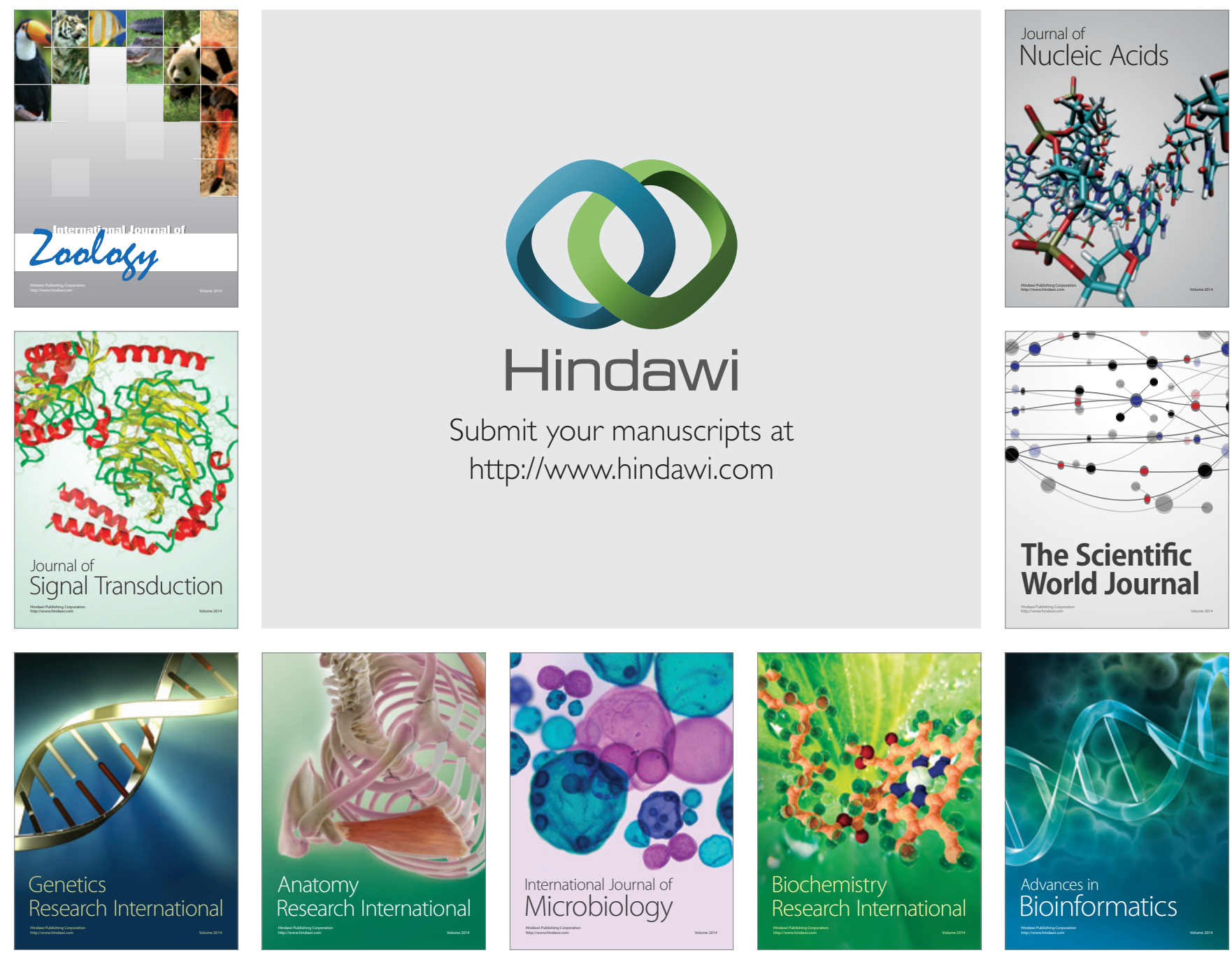

The Scientific World Journal
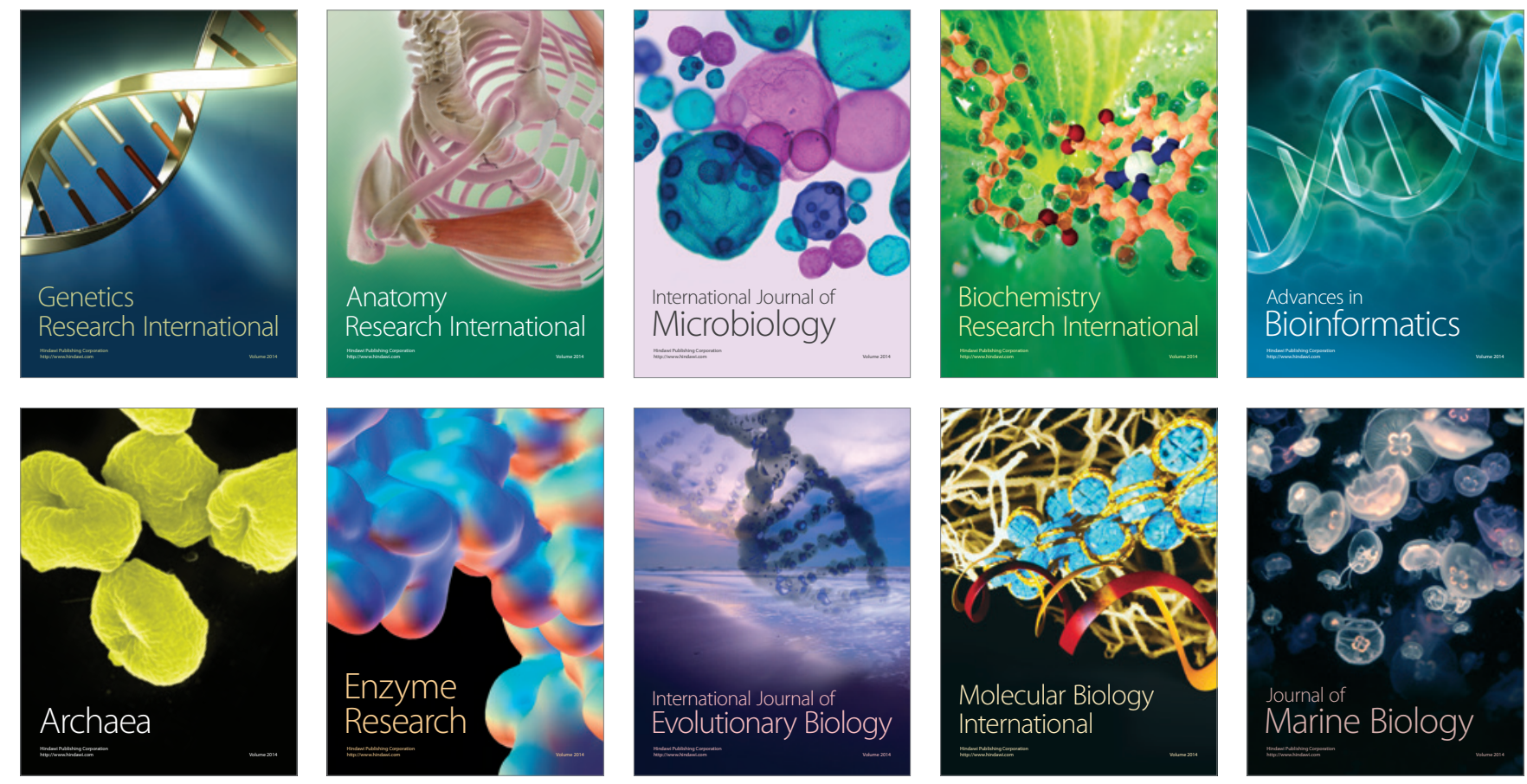